This item was submitted to Loughborough's Research Repository by the author.

Items in Figshare are protected by copyright, with all rights reserved, unless otherwise indicated.

\title{
How are management fashions institutionalized? The role of institutional
} work.

PLEASE CITE THE PUBLISHED VERSION

VERSION

AM (Accepted Manuscript)

LICENCE

CC BY-NC-ND 4.0

\section{REPOSITORY RECORD}

Perkmann, Markus, and Andre Spicer. 2019. "How Are Management Fashions Institutionalized? the Role of Institutional Work.”. figshare. https://hdl.handle.net/2134/3336. 
This item was submitted to Loughborough's Institutional Repository (https://dspace.lboro.ac.uk/) by the author and is made available under the following Creative Commons Licence conditions.

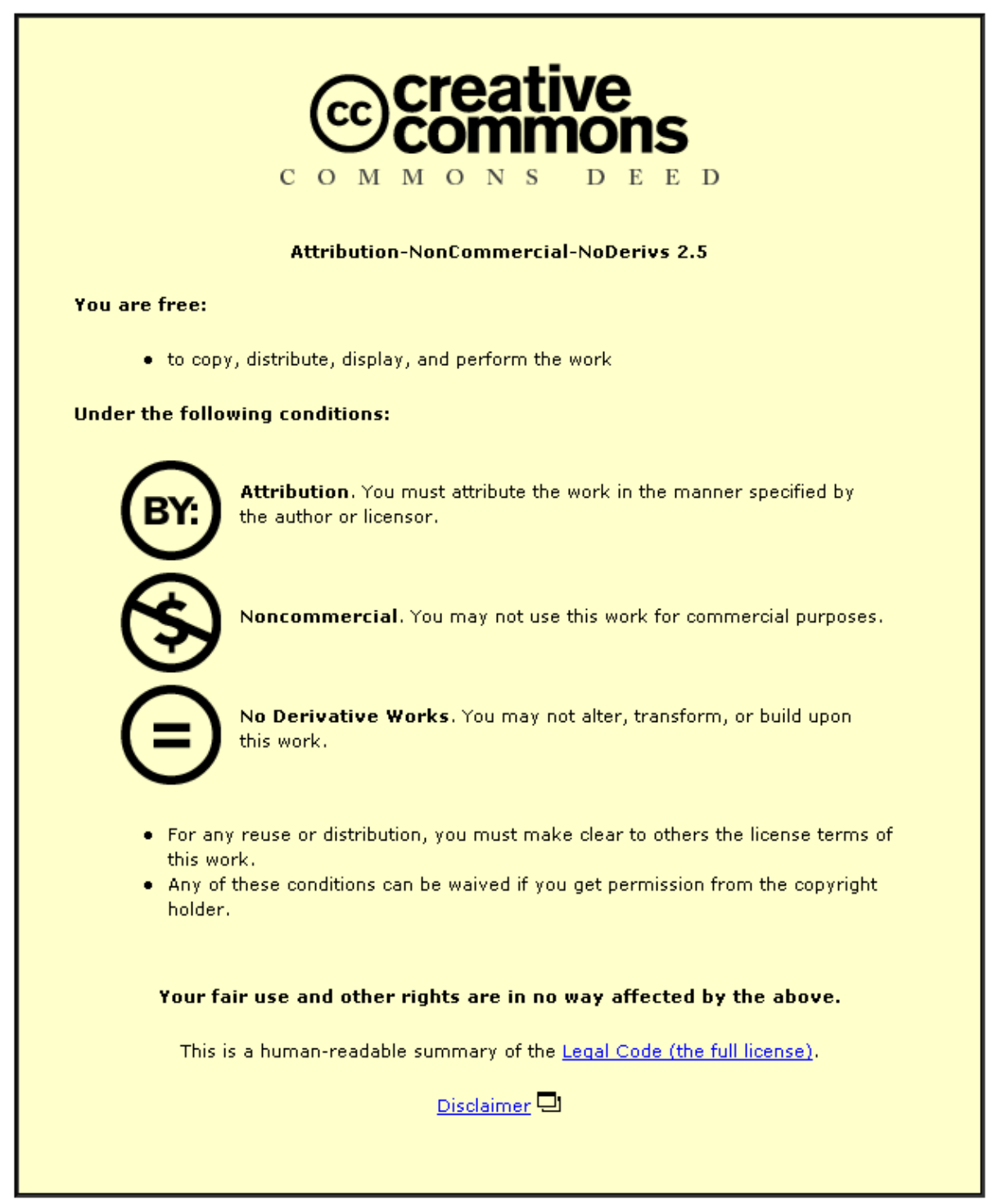

For the full text of this licence, please go to: http://creativecommons.org/licenses/by-nc-nd/2.5/ 
Forthcoming in Human Relations (2008)

\title{
How are management fashions institutionalized? The role of institutional work
}

Markus Perkmann and André Spicer

\begin{abstract}
We explore how transitory management fashions become institutionalized. Based on the concepts of institutional entrepreneurship and institutional work, we postulate that fashionable management practices acquire permanence when they are anchored within field-wide institutions. The building of such institutions requires various types of institutional work, including political work, technical work and cultural work. Based on a review of the empirical literature on various management fashions, we identify the actors engaging in these different types of works, and their skills. Our results suggest that the institutionalization effect is stronger if more types of institutional work are deployed and if the skill sets of the involved actors vary. We also argue that institutional construction in the case of management fashions is likely to take the form of decentralized 'partaking' rather than being led by a single dominant institutional entrepreneur. We conclude with implications for the study of management fashions and the role of agency in institutionalization.
\end{abstract}




\section{Introduction}

We often assume that managers are hard-nosed rationalists who adopt new management ideas to achieve important goals or improve existing practice. However, managers' decision to embrace new ideas is often informed by collective beliefs about rational or progressive managerial practice. These collective beliefs are shaped by idea providers such as consultants or gurus (Jackson, 2001; Micklethwait \& Wooldridge, 1996). They can therefore assume the characteristics of management fashions, leading to a 'relatively transitory collective belief, disseminated by management fashion setters, that a management technique leads rational management progress' (Abrahamson, 1996: 257). Some examples of management fashions include total quality management (Zbaracki, 1998), quality circles (Abrahamson \& Fairchild, 1999), team-working (Mueller, Proctor, \& Buchanan, 2000), integrated marketing communication (Cornelissen \& Lock, 2000), and business process reengineering (de Cock \& Hipkin, 1997).

Management fashions consist of practices and discourses associated with them (Benders \& van Veen, 2001). Discourses are bodies of talk and text which constitute a particular practice as popular, important and widely applicable. Studies have found that discourses associated with management fashions move in a recognisable cycle. Initially, new managerial ideas emerge in response to perceived shortcomings of current practice. They are subsequently appropriated and promoted by fashion industries populated by gurus, consultants and publishers (Sahlin-Andersson \& Engwall, 2002). Finally, the fashion will fade as the gaps between its promises and the reality of implementation become increasingly apparent (Abrahamson, 1991). This means the life of management fashions typically follows a bellshaped curve with early adoption followed by wide-spread up-take and an eventual downturn (Abrahamson \& Fairchild, 1999). While during the early phase emotionally charged and enthusiastic discourses are typical, the downturn is dominated by more rational and critical discourse (Abrahamson \& Fairchild, 1999). This indicates a pattern of learning whereby superstitious learning is superseded by rational learning when the fashion does not deliver what it promised (Argyris \& Schön, 1978).

In view of the bell-shaped curve, we would suspect that few management fashions would survive the initial celebrations. Proponents of management fashion theory suggest that the discourse associated with a management fashion eventually declines and the fashion including its underlying practice will eventually be forgotten (Abrahamson \& Fairchild, 1999). However, existing research indicates that the practices associated with some management 
fashions do not necessarily disappear even when the discourse fades. For instance, the once fashionable discourse of Total Quality Management (TQM) has had lasting effects on how organizations address quality-related issues (Thomas \& William, 2001). Similarly, unit management, a management fad popular during the 1960s, continued to be practiced even after the publicity boom had ebbed (Burns \& Wholey, 1993). In each of these cases the practice persisted when the discourse began to disappear, indicating they became institutionalized. In other words, they became 'taken for granted by members of a social group as efficacious and necessary' (Tolbert \& Zucker, 1996). This happens when an actual practice (and not just the discourse) associated with a management fashion becomes broadly accepted as important, reasonable, and vital.

Yet there has been little research on management fashions after they have become unfashionable. In this article we explore how a management fashion becomes an institution. We ask under what conditions a management fashion becomes more permanently diffused. In particular, we are interested in the social agency underlying the institutionalization of a practice. We argue that a management fashion becomes an institution due to institutional work performed by various actors (Lawrence \& Suddaby, 2006). We claim purposeful action results in establishing and maintaining a management fashion as an accepted element of organizational life. This implies an institutional infrastructure is built within and across organizational fields to which actual and potential adopter organizations are exposed. Different kinds of institutional work are involved: political work is aimed at generating new configurations of actors and establishing and reconfiguring rules and property rights; technical work involves designing frameworks that suggest, recommend or prescribe certain course of action; cultural work, finally, establishes or reframes belief systems and values, often by linking practices with more widely anchored discourses (Lawrence \& Suddaby, 2006; Perkmann \& Spicer, 2007).

We argue that turning a fashion into an institution requires a wide range of institutional work. This means it is rarely, if ever, achieved by a lone institutional entrepreneur (Greenwood \& Suddaby, 2006). Rather, a fashion becomes an institution through a process of collective institutional entrepreneurship whereby several actors with differing skills work in parallel. In order to explore these dynamics we first review existing analyses of how a fashion becomes an institution. Building on these, we argue that the concept of institutional entrepreneurship provides an insightful starting point for the analysis of agency underpinning the entrenchment of a fashion into an institution. We then outline what institutional entrepreneurs do and how they do it. Using these insights we turn to the literature on management fashions and examine 
the political, technical and cultural projects involved in making them into institutions. We discuss our results by formulating several propositions and conclude by reflecting on the implications for the study of management fashions and institutional entrepreneurship.

\section{From fashion to institution}

Abrahamson and Fairchild (1999: 710) note that there is 'precious little research examining why certain fashions become institutionalized and others do not'. They offer a theoretical starting point rooted in evolutionary theory. An 'ecological theory of fashions and institutions', the authors reason, should explain the variation of management practices, their selection by adopters and their longer-term retention even after the fashionable discourse has ebbed. Yet while their approach offers explanations for the variation and selection stages, as well as the abandonment of management fashions, they remain silent on the processes and conditions relating to the retention of fashions.

This limitation is a consequence of Abrahamson's (1996) ambivalent usage of neoinstitutionalist theory. On one hand, he argues that fashion discourses appeal to the general value of rationality, in line with Meyer and Rowan's (1977) argument that organizations tend to adopt legitimate rather than technically efficient structures. In other words, the argument goes that new management ideas diffuse primarily via isomorphic pressures across organizations. On the other, however, he points to the counter-institutionalizing forces that prevent the practices from being stabilized. These forces stem from 'both norms of progress and the financial interests of the knowledge entrepreneurs in debunking incipient institutions in order to continue profiting from the progressive appetite of fashion consumers for ever-new management fashions' (Abrahamson \& Fairchild, 1999). The fashion-setting industry subverts institutionalizing forces by continuously producing new fashions. This means the very structure of Abrahamson's argument prevents him to explain why and when management fashions would lead to institutionalization.

To provide a remedy, Zeitz, Mittal and McAulay (1999) distinguish between the transitory adoption of a practice and its enduring 'entrenchment'. Entrenchment is defined as the institutionalization of a practice to the extent that it is unlikely to be abandoned. They argue that while the mere adoption of a practice indicates the exposure to a fashion, entrenchment is required to induce a lasting change of practice. They identify five 'pillars' by which a fashionable concept can become entrenched: models (spurring imitation), culture (promoting identification), education (again spurring imitation), regulative/coercive influences (exerting power) and technical-rational influences (providing recipes for improving performance). 
Assuming that such entrenchment can occur at different levels of analysis, from individual, organizational, inter-organizational to the societal level, they propose a set of 'indicators' that can be used for empirically assessing as to whether a practice has become entrenched: formalization, compatibility (with other practices), depth, systematic coherence (with other concepts and strategies) and the existence of 'webs of interdependencies' (Zeitz, Mittal, \& McAulay, 1999). Zeitz and colleagues' distinction between adoption and entrenchment highlights that fashions can be preludes to the institutionalization of specific practices across organizational fields. Yet while their matrix framework considers multiple levels of analysis and multiple pillars of this process, they fail to identify the actors and activities involved in 'entrenching' a management fashion.

This shortcoming is addressed to some extent by Scarbrough (2002) who argues that a range of groups participate not just in 'fashion setting', but also subsequent institutionalization. The latter process is seen being driving by the 'translation' of practices into specific organizational contexts whereby both professional groups and consultants play a crucial role. This study takes the crucial step of identifying who is involved in the process of institutionalizing a management fashion. Yet it does not account in detail for the activities these actors engage in. Suddaby and Greenwood (2001) shed some light on this question by identifying the processes involved in the generation and diffusion of a management fashion. They argue that management knowledge is generated in a four stage cycle: legimitation, commodification, colonization, and due diligence and innovation. Each of these stages involves different actors: while opinion leaders such as 'gurus' are responsible for the initial legitimation of certain bodies of knowledge, large consulting firms are seen as the main protagonists during commodification and colonization. By contrast, business schools are often protagonists in due diligence and innovation. These findings illustrate the multi-actor quality of the production of management knowledge whereby different activities in this process might be carried out by different types of actors. The general argument is mirrored by Abrahamson and Fairchild who argue that knowledge communities involving various 'idea entrepreneurs' such as consultants, academics and gurus seek to generate knowledge about new practices and generate interest in them (Abrahamson \& Fairchild, 2001). While Suddaby and Greenwood (2001) provide a sense of what various actors do to institutionalize a management fashion, they do not specify in detail the actual activities involved. More importantly, their cycle model has functionalist overtones as it fails to state the conditions under which the knowledge generation cycle will successfully evolve. 
In light of these inadequacies of extant work, in this paper we shall therefore ask how management fashions become institutionalized. To this purpose, we turn to recent theorizing on institutional work. We argue that institutional entrepreneurs undertake field-wide institutional work to entrench fashionable practices. These institution-changing actions of institutional entrepreneurs can be contrasted with the normal institution-following actions involved in the regular operations of organizations within a field (Lawrence, 1999). While the latter activities are informed by competitive strategies, i.e. the attempt of organizations to position themselves favourably within their field, institutional strategies are aimed at changing the parameters according to which competitive strategies are played out (Lawrence, 1999). In order to explore processes of institutional change, we shall now turn to the literature on 'institutional work' (Lawrence and Suddaby, 2006).

\section{Institutional work}

Institutions are conventions among social actors that are self-policing (Douglas, 1986). They are taken-for-granted 'cultured-cognitive, normative and regulative elements that ... provide stability and meaning to social life' (Scott, 1995). The study of institutions has long focused on how institutions exert stabilizing influence on social processes (DiMaggio \& Powell, 1983). A more recent body of work has explored how institutions change (Colomy, 1998; DiMaggio, 1988). In particular, studies of institutional entrepreneurship have sought to uncover the agency dimension underpinning institutional change (Eisenstadt, 1980; Fligstein, 1997; Garud, Jain, \& Kumaraswamy, 2002). Institutional entrepreneurs are agents who intentionally and purposefully work towards changing existing or creating novel institutions. The defining activity of institutional entrepreneurs is represented by mobilizing 'projective' agency (Dorado, 2005). This involves 'the imaginative generation by actors of possible future trajectories of action, in which received structures of thought and action may be creatively reconfigured in relation to actors' hopes, fears, and desires for the future' (Emirbayer \& Mische, 1998: 971). The imagined trajectories provide the 'content' for change processes, and enable institutional entrepreneurs to 'address a vital problem or societal need' and propose a remedy, specifying the functions and goals to be fulfilled by the proposed alteration (Colomy, 1998: 272).

Yet institutional entrepreneurship is not the only mode in which agency impacts on institutional change. In many circumstances, institutionalization is driven by a more marketlike logic of decentralized adoption with no easily identifiable institutional entrepreneurs (Leblebici et al., 1991). Dorado (2005) has referred to this logic of institutional emergence as 
'partaking'. Furthermore, she identifies 'convening' as a mode of institutional change fuelled by efforts of actors to bring together a set of organizations interested in change (Dorado, 2005).

These agential processes of institutional change have in common that they require purposeful efforts. This is what Lawrence and Suddaby call institutional work, defined as "purposive action of individuals and organizations aimed at creating, maintaining and disrupting institutions' (Lawrence \& Suddaby, 2006: 214). Institutional work comprises various activities that may for instance each address the regulative, normative and cognitive 'pillars' of an institution (Scott, 1995). Furthermore, in order to undertake institutional work, actors require certain skills. Fligstein (1997) argues that they require 'social skills', involving the 'ability to induce co-operation in others'. This might include the ability to exert authority, set agendas, frame arguments, creatively bring together unusual components and engage in bargaining and brokering (Fligstein, 1997). Typically, these skills are embodied within certain actors, particularly if there is a division of labour amongst different groups who seek to change institutions (Campbell, 2004). As a result, some actors might specialize in certain kinds of institutional work.

Lawrence and Suddaby's (2006) framework and empirical work on the activities involved in institutional entrepreneurship (Perkmann \& Spicer, 2007) suggest three main types of institutional work: political work, technical work and cultural work. Associated with each of these activities are specific skills and actors. In what follows we shall work through each of the sets of work, skills and actors in turn.

The first type of institutional work is political work. This involves influencing the development of rules, property rights and boundaries in the attempt to anchor an institution within the wider social system (Lawrence \& Suddaby, 2006). Political work hence refers mainly to the regulative pillar of institutions, involving the building of rules and regulations (Scott, 1995). Political work includes activities such as advocating a practice to other actors through direct social suasion, defining boundaries between who is inside and outside the social system, and vesting certain interested actors with specific roles and rights (Lawrence \& Suddaby, 2006). To undertake this work, institutional entrepreneurs must possess political skills. Such skills enable them to enrol other actors into specific roles by creating alignment between their interests and the institution (Garud, Jain, \& Kumaraswamy, 2002). This skill is likely to be particularly concentrated among actors who specialize in engineering linkages between groups who have differing interests, as for instance politicians, trade unions, lobbyists, industry associations, and advocacy organizations (Campbell, 2004). 
Political work provides a social basis on which an institution can be constructed but it does not provide detailed models of how an institution functions. This requires technical work, relating to the cognitive-cultural pillar of institutions involving the construction of 'mental models' and shared world views (Scott, 1995). Crafting categorizations, cause-and-effect schemata and projections are part of this work. Institutional entrepreneurs can pursue such technical work in different ways: though mimicry, creating links between a new practice and already institutionalized practices; through theorization, establishing abstract models of an institution; and educating other actors so they are enabled to use these abstract models (Lawrence \& Suddaby, 2006). To undertake this kind of work, institutional entrepreneurs need analytical skills, i.e. the ability to develop abstract models and representations of an institution (Strang \& Meyer, 1993). These skills are likely to be concentrated amongst actors with technical, technocratic or expert competences, such as social scientists, consultants, academics, and other professionals.

The models provided by technical work give an institution a degree of rigour, meaning that it can be more easily transported from one setting to another. Yet technical work is less efficacious for making actors 'attached' to an institution. To achieve this, institutional entrepreneurs engage in cultural work, relating to the normative pillar which stipulates common ways of acting and behaving (Scott, 1995). Cultural work involves presenting an institution in a way that appeals to a wider audience beyond those who have an immediate interest or technical stake in an institution. Institutional entrepreneurs can target other actors' belief systems by shaping their identities and thus encourage them to enact an institution (Creed, Scully, \& Austin, 2002). Often this involves grounding a practice in a broader normative framework, and constructing networks with other organizations to provide the practice with some degree of normative sanction (Lawrence \& Suddaby, 2006; Zilber, 2002). These tasks require cultural skills. In particular, they must be able to frame an institution in terms of broader values, building it into specific normative attitudes and create common identities (Ansell, 1997). These skills tend to be concentrated amongst groups who are able to monitor and manipulate public opinion and perceptions, such as journalists, public relations experts, advertising agencies, social movements and intellectuals (Campbell, 2004).

Existing work on institutional entrepreneurship provides a useful way of thinking about the practices involved in entrenching an institution. However, we do not know whether these different types of work are indeed also present in the case of management fashions, and, if this were the case, exactly what activities we would find. We also do not know the role of different actors in carrying out different forms of institutional work in the specific case of 
management fashions. Finally, there is little clarity about whether and how these different forms of institutional work relate to each other. Below, we seek to answer these questions through a systematic review of the literature on management fashions.

\section{Making a fashion into an institution}

To explore the institutional work underlying the institutionalization of management fashions, we carried out a systematic literature review. Using the Google Scholar bibliographic search facility, we identified all scholarly articles and books containing empirical analyses of how management practices are institutionalized. Google Scholar turns out results on the basis of their fit with the search terms, sorted according to number of citations. Given the fuzzy character of our search criteria, Google Scholar proved more suitable than more structured bibliographic databases. In our search criteria, we combined terms such as 'diffusion', 'institutionalization', 'adoption' with concepts such as 'management practices' and 'organizational practices'. We also compiled a list of the most 'fashionable' practices as mentioned in the fashion literature, and searched for sources specifically relating to them. Among the results, we discarded works that dealt exclusively with the fashion aspect of practices, without providing evidence on their actual adoption and diffusion. We also discarded contributions focusing on the impact and modalities of management practices they represented the majority of the articles - retaining only those exploring the circumstances of their adoption and diffusion. This yielded 26 articles.

We then worked through each of the articles to identify what processes were documented in transforming a management fashion into an institution. In particular, we looked for instances of institutional work present in each case whereby we relied on categories derived from Lawrence and Suddaby's (2006) framework of institutional work. For each of the sources, we identified (a) what management fashion was analysed, (b) what type of institutional work was carried out, (c) what activities this specifically involved, (d) and the actors involved. Results are compiled in Table 1.

Table 1 about here

We synthesized the results by grouping the identified activities according to the categories by Lawrence and Suddaby (2006). This also allowed us to establish what actors were predominantly associated with each type of activity. From these results, we built a second 
table identifying for each kind of institutional work, how it is done, and the actors responsible for it (Table 2). Below, we present the results of our analysis of this literature.

\section{Political Work}

Political work involves generating social support for a practice by recruiting relevant actors into coalitions and networks and establishing rules and regulations. Going through our body of sources, we identified various instances in which actors used political work to promote fashionable management practices.

Notably, previous research recounts how actors engaged in 'advocacy', involving attempts to gather political support for a practice via social suasion (Mintrom \& Vergari, 1996). Cole (1985) shows how Swedish trade unions advocated small-group activity as being in the interest of their members and therefore provided a major push for the uptake of the practice within Swedish companies. He also shows that in other institutional contexts, such as the USA, organizations attempted to become advocates of the new practice yet their lobbying strategies failed to gather the support necessary to push for the changes. For instance, the American Productivity Centre failed to gain support for the practice from the industrial members on its board. By contrast, in Japan powerful employers' organizations supported the practice and, as a result, specialized organizations such as the Japan Union of Scientists and Engineers were able to assume a leadership role in developing and diffusing the concept of quality control circles. Cole's research suggests that employer associations and trade unions organizations can become engaged in advocacy by promoting practices they deem in the interest of their members or stakeholders within bipartite or tripartite industrial relations systems.

Standards organizations can also become the target of fashion advocates. Such organizations are usually relatively open towards stakeholders and parties interested in standardizing certain technologies or practices (Lehr, 1992). This provides significant opportunities for 'political entrepreneurs' who are able to engineer collaboration amongst a range of players within an industry to pursue a collective goal such as promoting a management fashion (Botzem \& Quack, 2006). These political entrepreneurs might be dominant players within an industry (Perry \& Noelke, 2005), professional bodies (Botzem \& Quack, 2006), the State (Guler, Guillen, \& Macpherson, 2002) or non-governmental organizations (Meidinger, 1997). In order to engage in lobbying, these groups must have some skill in forming coalitions, invoking the common interest and mobilizing support amongst a diverse range of stakeholders (Pelkmans, 2001). 
In some cases, the advocates of a practice address the State in the attempt to influence legislation. For instance, legislation significantly shaped the bureaucratization and formalization of the employment relationship in the early $20^{\text {th }}$ century (Baron, Dobbin, $\&$ Jennings, 1986); equally, legislation on equal rights and affirmative action spurned HR practices conducive to internal labour markets (Dobbin et al., 1993). State regulation was also present, at least as a threat, in the case of environmental practices, such as the mandated recycling of old cars (Orsato, den Hond, \& Clegg, 2002). In some cases, advocacy work can even result in the codification of practices within the rule frameworks of public administration, involving for instance the conferring of certain roles or powers to specific groups with an intrinsic interest in those practices. Such vesting (Lawrence \& Suddaby, 2006) can be observed in the case of certain human resource and finance practices. For instance, the US personnel managers profession was able to escape decline in the immediate aftermath of world-war II during which it had held an exceptional role by taking care of governmentmandated practices such as unemployment insurance, pension benefits and safety regulations (Baron, Dobbin, \& Jennings, 1986).

Other practices, such as environmental practices standardized via ISO 14000, diffused without significant coercive pressures exerted by the State (Viadiu, Fa, \& Saizarbitoria, 2006). In yet other cases, advocacy addresses the 'public' more generally, particularly when promoters of a practice, such as business interest organizations, seek to generate legitimacy across a range of different stakeholders. Such patterns were observed in the case of the introduction of TQM in Turkey (Özen \& Berkman, 2007).

As well as directly advocating a management fashion, institutional entrepreneurs also use defining work to promote a fashion. This involves creating social boundaries to delineate who is allowed to use a certain practice as well as establishing status hierarchies within communities of practice (Lawrence \& Suddaby, 2006), for instance via membership rules (Lawrence, 1999). For management practices, certification is an important way for putting such definitions in place. For instance, the diffusion of quality management practices was significantly influenced by the defining work carried out by certification agencies via the award of ISO 9000 certificates (Guler, Guillen, \& Macpherson, 2002). As a result, even though certification is voluntary and costly, organizations seek certification in the attempt to claim membership in the community of those using the underlying quality management practices.

Summarizing, by engaging in political work, promoters of a management fashion are able to create networks of social relations and rules around that fashion. This work might include 
advocating a certain fashion to field-wide organizations, vesting interested parties via rulesetting and property rights attribution and defining the social boundaries of adoption and usage.

\section{Technical work}

We encountered a variety of instances where promoters of fashionable practices deployed technical work, via various activities. A first activity we frequently found was theorization. An example of can be found in the history of TQM as recounted in a study by David and Strang (2006). When TQM was booming as a management fashion, it was promoted mainly by generalist consultancies with weak expertise in the technical foundations of the practice. By contrast, when the fashion declined, the consulting field became increasingly populated by technically sophisticated specialists. This corresponded to different demand characteristics as corporate clients' competence and sophistication grew in time. Technically oriented consultancies contributed to operationalizing, refining and formalizing the practice underpinning TQM. Specialist consultancy firms had deep knowledge of TQM principles, unlike the generalists who operated with only superficial knowledge embodied in standard templates. The broader lesson is that "the emergence of a hard core of knowledgeable TQM providers is likely to improve average program success, refine industry best practice, and increase the legitimacy of a technique suffering from disillusionment and scepticism" (David \& Strang, 2006: 231). By engaging in technical work around the fashionable practice, the specialist providers contributed to the institutionalization of the practice.

The lesson from this case is that promoters of a management fashion choose theorization to give the underlying practice some degree of rigour (Greenwood, Suddaby, \& Hinings, 2002). This involves developing an adequate theoretical model of a practice, specifying the failings of old recipes and generating legitimacy around the new ones (Tolbert \& Zucker, 1996). Such formalization occurs when a specific body of expertise is codified into templates, procedures, manuals or tools that (a) can be administered in a similar manner by others in different contexts, and (b) communicated convincingly and effectively to top management, internal clients and other stakeholders (Suddaby \& Greenwood, 2001).

Another activity involved in technical work is standardization. This involves the development of generally accepted and mandated rules with respect to a management practice. Some practices, notably TQM and the management of environmental impact, have been codified into official standards, such as ISO 9000 and ISO 14000. The activity of standardizing the body of knowledge is a technical activity that differs from the political work described above, with the latter consisting in lobbying standards organizations to initiate work on certain 
standards in the first place. Standardization strategies are aimed at reducing ambiguities and transforming a loosely described practice into precise programmes that can be routinely implemented and commercially sold by certification agents. The existence of standards is independent from the question as to whether the reality of organizational implementation is effectively as homogenous as claimed by the standardizing agents (Zbaracki, 1998). Although published evidence is weak, anecdotal insights suggest that consulting organizations and professional bodies are usually strongly represented on the technical committees used for elaborating standards at organizations such as International Organization for Standardization (ISO) (Botzem \& Quack, 2006; Hallström, 2004; Perry \& Noelke, 2005).

Another type of technical work is to align a new practice with existing common practice. A historical example of such mimicry is Edison's attempts to make electric lighting appear as similar as possible to gas lighting (Hargadon \& Douglas, 2001). Related efforts can be observed in the case of some management practices even though in the upturn phase of fashion cycles the innovativeness and radicalness of practices is usually emphasized (Carson et al., 2000). For instance, in order for ISO 14000 to be widely accepted, it was designed in close alignment with the principles underpinning ISO 9000 (Viadiu, Fa, \& Saizarbitoria, 2006). Knowledge management practices were adapted and designed to be aligned with the design of large-scale information systems (Scarbrough, 2002). An important aspect of facilitating mimicry is to ensure some degree of ambiguity. Studies of management fashions have used concepts such as 'pragmatic ambiguity' (Giroux, 2006) or 'interpretive viability' (Benders \& van Veen, 2001) to describe this ambiguity inherent in management fashions. This allows adopters in organizations to adopt management fashions opportunistically, for instance to legitimate organizational re-structuring programmes in collaboration with consultants (Benders \& van Veen, 2001).

A yet different type of technical work we encountered was represented by educational activities. This involved imparting the skills and technology required to 'correctly' use a management fashion. This can occur through informal learning by allowing other managers to observe practices at work. For instance, the spread of teamwork in the European automobile industry was facilitated by European executives visiting Japanese manufacturers (Woywode, 2002). Education may also occur formally, such as via management training offered by providers internal and external to organizations. In post-war Europe, USA management practices were imparted to a new generation of managers through a new type of management education under the label of 'modern management methods' (Djelic, 1998: 211-215). Educating practicing and future managers in these techniques meant that the latter came to be 
seen as part of the standard tool-box of a modern manager. Eventually, training in these modern management techniques was further institutionalized through changing the curriculum of higher education institutions. During the early 1950s the curricula of French commercial schools such as the HEC were redesigned to reflect the concerns of modern management (Djelic, 1998). Another example of educating activities is provided by Lounsbury and Crumley's study (2007) on the birth of active money management that was facilitated by the creation of a standardized education curriculum for new style fund managers.

In sum, technical work furthers the entrenchment of management practices in a number of ways. First, actors such as specialist consultancies engage in theorization. This involves elaborating models and processes for management practices aimed at generating predictable results and receiving credibility from expert practice users. This might result in the creation of widely accepted official standards. Second, technical work can be aimed at making practices to appear similar to known models to promote increased uptake. Finally, educating participants contributes to make transient fashions accessible to broader audiences. These types of technical work can therefore contribute to turning management fashions from being rather vague concepts into more specific and operational concepts that can be understood and implemented by adopters.

\section{Cultural work}

Having shown how promoters of fashionable practices deploy political and technical work, we now turn to cultural work, i.e. activities to frame practices in ways that appeal to broader audiences (Benford \& Snow, 2000). Typically, this occurs by promoting discourses that associate practices with widely accepted norms and values.

The most prominent form this takes in the diffusion of management fashions is the development of professionalized bodies of expertise. The existence of professions has long been identified as a source of normative isomorphic pressures that leads organizations to adopt similar practices or templates on the basis of normative legitimacy (DiMaggio \& Powell, 1983; Ruef \& Scott, 1998). For several reasons, professionalization plays an important role in institutionalizing fashionable practices. First, the professionalization of specific bodies of expertise often goes hand in hand with the establishment of organizations who actively drive the supply of professionals trained in this specific type of expertise. They usually act on a field-wide basis and can therefore be seen as anchoring the practice across fields, relatively independently from the adopting organizations. Greenwood et al.'s (2002) study of the accounting profession in Canada illustrates how a professional association lead 
successful attempts to institutionalize a new organizational form for professional services firms. In his historic analysis of the adoption of different models of management in four countries, Guillén (1994) emphasises the role of professional groups in informing the adoption of the techniques of a paradigm. Shenhav's (1995) work demonstrates that the 'system' view of organizations originated as a professional project from within the engineering profession who sought industrial legitimation and whose professional paradigm spilled over into the managerial field. The building of professions can be subsumed under a general category of institutional work, that is building normative networks (Lawrence \& Suddaby, 2006). This involves constructing 'interorganizational connections through which practices become normatively sanctioned and which form the relevant peer group with respect to normative compliance and monitoring' (Lawrence \& Suddaby, 2006: 224-5).

A related way in which cultural work is deployed is by changing or expanding the remit of existing professional groups in order to accommodate new practices. Professional organizations can extend the 'jurisdiction' of their professional knowledge (Abbott, 1988), i.e. the spaces of activity for which their members claim responsibility. Any emerging profession will have to make some claims in terms of its jurisdiction. This will often involve a contestation of existing professions' jurisdictions. Scarbrough (2002) argues that by engaging in 'colonization', professionals interpret new ideas in ways that builds into their professional expertise and ultimately serves their interest. He provides the example of knowledge management where information technology professionals interpreted the new ideas about managing knowledge in a way that led to the development of new information management systems. In related work, a process akin to such jurisdictional migration is described by Suddaby and Greenwood (2001), implying the expansion of the intended use of a body of management knowledge to include new tasks and areas of intervention. To illustrate this process, they describe how the 'Big Five' accounting firms turned to new activities that offered higher profit and less risk, including management consulting and legal services. We also found work directed at constructing identities. If the exposure to a management fashion is something akin to the spread of a social movement (Strang \& Soule, 1998), then identity formation will be one of the primary components of the recruitment of fashion adopters. As the existence of professional identities plays an important role in the development and operation of professions (Ibarra, 1999), the followers and proponents of a management fashions inside organisations will start to differentiate themselves as a distinct functional group. For instance, early personnel professionals were instrumental in building the 
new profession's identity around new practices, such as work roles and turnover management (Baron, Dobbin, \& Jennings, 1986).

We found professionalization and the definition of professional jurisdictions as significant instances where cultural work was pursued to promote management fashions. This involved activities focusing on constructing stable normative network, changing associations and jurisdictions and shaping identities. This illustrates how institutional entrepreneurs can embed a fashionable management practice within wider systems of values, notably professional skills and identities.

Table 2 about here

\section{Discussion}

Our analysis of the empirical literature reveals that proponents of fashions deploy various types of institutional work, comprising different activities and involving different actors. We now synthesise our insights to establish under what conditions the deployment of institutional work will lead to institutionalisation. To this purpose, we explore the relationship between different types of institutional work, the role of different actors, and how these actors relate to each other when carrying out institutional work.

\section{Multiple forms of institutional work}

Our analysis of existing accounts of fashions demonstrates the multi-faceted nature of the work deployed to stabilize them. We have typified this work into political, technical and cultural work. What does this tell us about the relationship between fashions, institutional work and institutionalization? The appearance of a fashion, as indicated by increased publication volumes, could simply be the consequence of institutional work being carried out. For instance, when a certain management practice is advocated by proponents via political work, this can be expected to result in stronger publishing activity around the practice (Cole, 1985), hence making it 'fashionable'. Equally, technical work and cultural work will each leave their traces in the media and hence reinforce the fashion. Institutional work could therefore simply be an antecedent of a rising fashion curve but there is no guarantee that this will lead to permanent institutionalization.

The question therefore is under what conditions the institutional work associated with a fashion is more likely to be successful. Institutional theory provides a clue by emphasizing 
that institutions have different pillars: rules and regulations, cognitive schemas, and normative frameworks (Scott, 1995). As political, technical and cultural work each address mainly one of these pillars, there will be a stronger institutionalization effect if they are deployed concurrently. This means that comprehensive institutional change occurs when all three pillars undergo significant modifications (Campbell, 2004), particularly if one views the various dimensions of institutions as being intertwined empirically (Hirsch, 1997). Previous models of institutional change have postulated such multidimensionality, as for instance Hoffman's (1999) framework that proposes a cumulative dynamic involving regulative, normative and cognitive aspects, with the presence of the latter indicating the most entrenched institutions. Although the interrelations between the pillars might vary, the most durable strategies of institutional change are those that are underpinned by the 'multi-aspect' nature of institutional change (Hoffman \& Ventresca, 1999).

The fashion literature provides examples for the efficacy of multi-dimensional institutional work for stabilizing practices. For instance, US-style management techniques were popularized throughout Europe following World War with a mixture of different forms of institutional work (Djelic, 1998). Political work such as via the Marshall Fund and lobbying activities of various arms of US government were important. In addition, technical work leading to the spread of management training and business schools, and cultural work, aiming at the construction of the identity of the professional manager, provided an impetus for institutionalization. Similarly, TQM was propagated through a combination of different forms of institutional work. Political work was evident in the way governments and standards organizations were urged to support TQM practices (Guler, Guillen, \& Macpherson, 2002). Proponents of TQM also engaged in technical work by building formal standards and schemata around quality which could be used by technical experts (David \& Strang, 2006). Finally, TQM was supported by through cultural work, including the establishment of professional associations and the building of the role identity of the quality manager (Özen \& Berkman, 2007; Zbaracki, 1998).

By contrast, in cases where efforts were limited to one type of work, success was wanting. For instance, the guru promoters of 'excellence' (Peters \& Waterman, 1982) were able advocates for the fashion and invested significant cultural work through popular business books, speeches and consulting engagements (Carroll, 1983). However, excellence was never embodied in normative associations such as a professional groupings or identifiable professional roles nor was significant technical work deployed to generate rigorous standards and models. A similar fate befell business process reengineering (Hammer \& Champy, 1993). 
Significant work was deployed to establish technical models for reengineering and disseminate these models (Benders, Berg, \& Bijsterveld, 1998). However, less work went into building normative associations and identities around reengineering. The result is that reengineering had a significant effect on corporations during the 1990s, but has since subsided. For the fashion of 'knowledge management', the jury is still out as to whether it will become part of the permanent landscape of corporate functions yet it seems that the institutionalization of this fashion was hindered by the lack of an operational technical framework to underpin its basic principles (Scarbrough, 2002).

These considerations suggest that the deployment of institutional work in its different dimensions constitutes a necessary condition for sustainable institutionalization. We therefore postulate:

A management fashion is more likely to be institutionalized if it is propagated via a combination of political, technical and cultural work compared to a single type of institutional work.

\section{Multiple institutional workers}

Our second question concerns the role of actors within the institutionalization process. If different types of institutional work are involved, then the question is whether they are pursued by the same or different actors. Previous literature has established that actors play different roles in the institutionalization process (Campbell, 2004; Dorado, 2005).

Our review of the management fashions literature revealed various types of actors engaging in institutional work (Table 2). Political work tended to be deployed by actors such as unions, industry associations or other interest organizations such as NGOs or consumer groups. Technical work was carried out by experts groups such as technical consultancies, management scientists, think tanks, and, to an extent, professional associations. Finally, cultural work was the domain of professional organizations and proponents such as management 'gurus' (Clark \& Salaman, 1998; Jackson, 2001). Conceptually this makes sense as different types of actors specialize in different skills that predispose them to certain types of institutional work (Campbell, 2004; Perkmann \& Spicer, 2007). Previous research has pointed to the political skills needed to create alignment between different actors and institutions (Fligstein, 1997; Garud, Jain, \& Kumaraswamy, 2002), analytical skills to build technically elaborate an organizational practice (Beckert, 1999; Strang \& Meyer, 1993), and cultural skills to frame an institution in terms of broader values (Ansell, 1997). 
Our analysis suggests that enduring practices were institutionalized when various types of actors were involved. For instance, in the case of TQM, standards organizations and the state were lobbied during attempts to advocate the usefulness of TQM (Mendel, 2006). Similarly, specialist consultancies built operational models of TQM, deploying analytical skills (David $\&$ Strang, 2006). Finally, the ability to connect TQM with broader organizational frames and transform it into an accepted professional area of expertise was pursued by fledgling professional bodies (Knights \& McCabe, 1999). Another example is provided by the institutionalization of active money management techniques in the mutual fund industry (Lounsbury \& Crumley, 2007). In this case, professional organizations engaged in promoting and justifying the new type of practice, as well as in garnering political support whereas theorization was pursued by the publisher of an annual sourcebook considered the industry 'bible' (Lounsbury \& Crumley, 2007).

By contrast, less successful institutionalization attempts appear to be those which attract a limited range of actors and, hence, institutional work skills. For instance, attempts to promote the fashion of excellence appeared to attract mostly actors with cultural skills such as the ability to embed the practice in a discourse of ambition and progress (Peters \& Waterman, 1982). However, the involvement of actors with technical and political skills seemed to have been less pronounced in this case. The result was that promoters and enthusiasts were unable to give the fashion a technical specificity or edge (Carroll, 1983; Micklethwait \& Wooldridge, 1996) nor were they able to build extensive networks of political support. The result was that it proved influential for a time, yet it was unable to continue to muster support. It appears that fashions that attract several types of skills are more likely to be institutionalized than others. We postulate:

A management fashion is more likely to be institutionalized if it is propagated by actors bringing together several types of institutional skills compared to a reduced range of such skills.

\section{Cumulative institutional work}

If there is a division of labour between actors engaged in institutional work, the next question is whether there is co-ordination between the different forms of work. One possibility is that co-ordination of various forms of institutional work is provided by an institutional sponsor who would ultimately benefit from the widespread institutionalization of the fashion. According to some studies of institutional entrepreneurship, we would expect this to be the case. For instance, Java was promoted as a technical standard across the nascent internet software industry by Sun Microsystems (Garud, Jain, \& Kumaraswamy, 2002). In this case 
the main 'institutional worker', Sun Microsystems Inc, directly benefited in that its Java computer language became an industry standard. Powerful professional organizations have been found to play a role in instituting a new organizational form, the multi-services professional firm, within its industry context in Canada (Greenwood, Suddaby, \& Hinings, 2002). Similarly, individuals with high degrees of legitimacy within multiple social contexts were found to play a central role in instituting new practices within the emerging field of HIV/AIDS treatment in Canada (Maguire, Hardy, \& Lawrence, 2004).

In the evidence we reviewed, we did not observe such co-ordination amongst the actors involved in the institutionalization of a management fashion. To cite a high-profile example, Toyota was a major developer and user of 'lean manufacturing/production' (Benders \& van Bijsterveld, 2000). Although it allowed other manufacturers, consultants and academics to visit their production facilities and observe lean production at work, Toyota did not play a major role in promoting and propagating this fashion. Rather, the work of propagating lean production and other high-performance work practices was taken on by other actors such as consultancies, academics and interest organizations.

This suggests that the various inputs of institutional work behind institutionalizing a management fashion are not co-ordinated in a centralized way. Rather, it appears that efforts are distributed across a field. This is consistent with other work on institutional entrepreneurship which suggests that institutional entrepreneurs can be more elusive in the sense that they are widely distributed across organizational fields (Leblebici et al., 1991). Such decentralized processes of institutional emergence have been characterized as 'partaking' (Dorado, 2005). 'Partaking' consists of institutional change effected through a convergence over time of autonomous actions of many actors (Dorado, 2005). This means that institutional change is not brought about by design but emerges as the result of the collective yet uncoordinated actions of distributed actors (Van de Ven \& Garud, 1993). The result is similar to what is called a 'dominant design' in the study of technology evolution (Tushman \& Anderson, 1986). A dominant design is a generally accepted platform on which all subsequent incremental technological innovation is built.

This raises the question as to whether there is a logic underlying partaking. Synthesising our insights from the literature, we conjecture that this is a process where different actors expend institutional work at different points in time. In other words, we argue that there is a temporal logic in how partaking occurs. The building of an institution appears to be informed by a process logic where one type of activity builds on the results of previous activity, perhaps pursued by different actors (Leblebici et al., 1991). This leads us to our third proposition: 
A management fashion is more likely to become an institution through the cumulative results of different kinds of institutional work over time, compared to conjoint expenditure of institutional work at specific points in time.

\section{Conclusions}

In this article, we asked how a management fashion becomes an institution. We argued that fashionable practices can become institutions through the skilled institutional work of multiple actors. Our analysis of the management fashions literature suggests that this work is multifaceted, in line with more general accounts of institutional work (Lawrence \& Suddaby, 2006). Moreover, the effects of institutional work deployed by various participants accumulate over time. The result of this accumulation is that a fashionable concept becomes gradually accepted as an institution. The decentralized character of this process is illustrated by the fact that management fashions are multi-field phenomena that spread across different sectors and countries. Institutional entrepreneurs, i.e. identifiable organizations with a major impact on the institutionalization of a practice, are usually constrained by their field contexts and are therefore unlikely to act across a number of fields. For this reason, we argued that 'partaking' is the likely form the institutionalization of fashionable practices takes. The process of partaking involves a division of 'institutional labour', with different actors carrying out different types of work.

This article makes three distinct contributions to the study of management fashions. First, we identify the practices associated with the diffusion of a management fashion. By exploring the process dimension of institutional work, our account adds to previous contributions that seek to explain the institutionalization of management fashions with reference to the institutional conditions in the environment of organizations (Zeitz, Mittal, \& McAulay, 1999), the actors involved in institutionalization (Scarborough, 2002), and the process involved in propagating the discourse associated with a management fashion (Suddaby and Greenwood, 2001). We have identified three distinct types of work, and the associated concrete activities, involved in institutionalizing a fashionable management practice. This reminds us that fashions do also not simply become institutions 'through use' in the sense that the degree of (temporary) uptake by organizations informs the degree of institutionalization of a practice. Rather, the process is accompanied and reinforced through identifiable expenditures of institutional work, underpinned by conscious if partially effective efforts to generate lasting templates for organizational practices. 
Second, we provide an account of the role played by different actors involved in propagating an institution. We have argued that instead of one group of heroic actors such as management gurus (Clark and Salaman, 1998) driving the propagation of a management fashion, various actors are involved in the process. They include politically oriented actors such as unions and NGOs, technically oriented actors such as technical consultancies, and culturally oriented actors such as gurus. Though these findings are reflected in other studies (Suddaby and Greenwood, 2001; Scarborough, 2002), we extend these by demonstrating that different actors will tend to undertake different kinds of work. Moreover, we suggest that institutionalization success will depend on the availability of multiple skills such as the ability to build political networks, technical capabilities, and the ability to culturally frame a fashion. Third, we emphasise the cumulative nature of institutional work. Existing accounts often suggest that institutional work involves a co-ordinated centralized effort undertaken by one central institutional worker (Garud, Jain, \& Kumaraswamy, 2002). In contrast, we highlighted 'partaking' as an alternative to 'institutional entrepreneurship' that has received much attention in the recent literature (Garud, Hardy, \& Maguire, 2007). The institutionalization of management practices appears to be an area where clearly identifiable institutional entrepreneurs play a lesser role. Rather, we saw the impetus behind institutional change as highly distributed across a multiplicity of actors within organizational fields. Against the heroic concept of the strategically positioned, multi-skilled institutional entrepreneur, such partaking involves different organizations specializing in specific aspects of institutional transformation. Our analysis suggests that partaking is more effective if it involves institutional work addressing all analytical pillars of institutions, i.e. their regulative, cognitive and normative aspects. This result reinforces accounts of institutional change that emphasise the multiplex and distributed nature of participants in this process, refraining from an overly zealous celebration of powerful individual actors (Lounsbury \& Crumley, 2007). This article is based on a comprehensive review of the empirical literature on a number of management fashions. Though the use of secondary literature constitutes a strength in view of its synthetic potential, it is also a limitation. Many studies of fashionable practices address different types of research questions and can therefore provide only partial accounts of the institutional work involved. Our synthesis therefore constitutes only a starting point for further studies based on primary evidence and we invite testing of propositions against empirical evidence. For instance, in order to explore our suggestion that a fashion might become institutionalized through the combination of different types of work (proposition one), authors may track the diffusion of a fashionable practice and the types of work which 
are invested in it. Relative success could be measured by recording the uptake or a certain practice within a population of organizations. Institutional work might be operationalised by tracking the activities undertaken by some of the main promoters of a fashion. To explore our suggestion that fashions will become institutions if actors with a range of skills are involved (proposition two), a future study may track the development of a management fashion in relationship to the variety of skills possessed by promoters of the fashion. These skills levels might be measured through looking at the qualification, experience, and avowed expertise of the different promoters of each management fashion. In order to explore our suggestion that fashions become institutionalized through the accumulation of different kinds of work (proposition three), empirical studies might longitudinally track the kinds of institutional work expended in diffusing a fashion and establish network connections between the actors involved.

We also acknowledge further research is needed in some other areas which we know little about. We know little about the sequencing of different types of activity resulting in institutional change. While some case studies have suggested specific propositions in this respect (Hoffman, 1999; Perkmann \& Spicer, 2007), they might only apply in specific circumstances. We also need to know more about the co-ordination mechanisms that may be at work during partaking processes where a set of actors seemingly work in a decentralized manner to institutionalize certain practices. Network analyses, for instance, could help elucidate the connections between different actors in this process. In the same vein, discourse analyses could be deployed to explore whether all participants feed from the same discursive sources or whether there is convergence from different sources. Finally, it would worthwhile exploring the relationship between the uptake of practices by managers and the institutional work pursued in the environment of organizations. This should address the question in what way managers interact with the institutional workers, and to what degree managers themselves act as institutional workers. Research addressing these questions would provide important additional insights into the question as to how and when fashionable practices become more permanent features of organizational life.

\section{References}

Abbott, A. D. The system of professions: An essay on the division of expert labor. Chicago; London: University of Chicago Press, 1988.

Abrahamson, E. Managerial fads and fashions: the diffusion and rejection of innovations. The Academy of Management Review, 1991, 16(3), 586-612.

Abrahamson, E. Management fashion. Academy of Management Review, 1996, 21(1), 254285. 
Abrahamson, E., \& Fairchild, G. Management fashion: lifecycles, triggers, and collective learning processes. Administrative Science Quarterly, 1999, 44, 708-740.

Abrahamson, E., \& Fairchild, G. Knowledge industries and idea entrepreneurs: New dimensions of innovative products, services, and organizations. In C. B. Schoonhoven, \& E. Romanelli (Eds.), The entrepreneurship dynamic: Origins of entrepreneurship and the evolution of industries: 147-177. Stanford: Stanford University Press, 2001.

Ansell, C. K. Symbolic networks: The realignment of the French working class, 1887-1894. American Journal of Sociology 1997, 103(2), 359-390.

Argyris, C., \& Schön, D. A. Organizational learning: A theory of action perspective. Reading (Mass.): Addison-Wesley, 1978.

Baron, J. N., Dobbin, F. R., \& Jennings, P. D. War and peace: The evolution of modern personnel administration in US industry. American Journal of Sociology, 1986, 92(2), 350.

Beckert, J. Agency, entrepreneurs, and institutional change. The role of strategic choice and institutionalized practices in organizations. Organization Studies, 1999, 20(5), 777799.

Benders, J., Berg, R.-J. v. d., \& Bijsterveld, M. v. Hitch-hiking on a hype: Dutch consultants engineering re-engineering. Journal of Organizational Change Management, 1998, 11(3), 201-215.

Benders, J., \& van Bijsterveld, M. Leaning on lean: The reception of a management fashion in Germany. New Technology, Work and Employment, 2000, 15, 50-64.

Benders, J., \& van Veen, K. What's in a fashion? Interpretative viability and management fashions. Organization, 2001, 8(1), 33-53.

Benford, R. D., \& Snow, D. A. Framing processes and social movements: an overview and assessment. Annual Review of Sociology, 2000, 26(1), 611-639.

Botzem, S., \& Quack, S. Contested rules and shifting boundaries: international standard setting in accounting. In M.-L. Djelic, \& K. Sahlin-Andersson (Eds.), Transnational governance: institutional dynamics of regulation: 266-286. Cambridge: Cambridge University Press, 2006.

Burns, L. R., \& Wholey, D. R. Adoption and abandonment of matrix management programs: effects of organizational characteristics and interorganizational networks. Academy of Management Journal, 1993, 36(1), 106-138.

Campbell, J. L. Institutional change and globalization. Princeton, N.J.: Princeton University Press, 2004.

Carroll, D. T. A disappointing search for excellence. Harvard Business Review, 1983, 61(6), 78-88.

Carson, P. P., Lanier, P. A., Carson, K. D., \& Guidry, B. N. Clearing a path through the management fashion jungle: Some preliminary trailblazing. Academy of Management Journal, 2000, 43(6), 1143-1158.

Clark, T., \& Salaman, G. Telling tales: management gurus' narratives and the construction of managerial identity. Journal of Management Studies, 1998, 35(2), 137-161.

Cole, R. E. The macropolitics of organizational change: A comparative analysis of the spread of small-group activities. Administrative Science Quarterly, 1985, 30(4), 560-585.

Colomy, P. Neofunctionalism and neoinstitutionalism: Human agency and interest in institutional change. Sociological Forum, 1998, 13(2), 265-300. 
Cornelissen, J. P., \& Lock, A. R. Theoretical concept or management fashion? Examining the significance of IMC. Journal of Advertising Research, 2000, 40(5), 7-15.

Creed, W. E. D., Scully, M. A., \& Austin, J. R. Clothes make the person? The tailoring of legitimating accounts and the social construction of identity. Organization Science, 2002, 13(5), 475-496.

David, R. J., \& Strang, D. When fashion is fleeting: Transitory collective beliefs and the dynamics of TQM consulting. Academy of Management Journal, 2006, 49(2), 215233.

De Cock, C., Fitchett, J., \& Volkmann, C. Constructing the New Economy: a discursive perspective. British Journal of Management, 2005, 16(1), 37-49.

de Cock, C., \& Hipkin, I. TQM and BPR: beyond the beyond myth. Journal of Management Studies, 1997, 34(5), 659-675.

DiMaggio, P. J. Interest and agency in institutional theory. In L. G. Zucker (Ed.), Institutional patterns and organizations: culture and environment: 3-22. Cambridge, Mass.: Ballinger, 1988.

DiMaggio, P. J., \& Powell, W. W. The iron cage revisited: Institutional isomorphism and collective rationality in organizational fields. American Sociological Review, 1983, 48(April), 147-160.

Djelic, M.-L. Exporting the American model: the post-war transformation of European business. Oxford: Oxford University Press, 1998.

Dobbin, F., Sutton, J. R., Meyer, J. W., \& Scott, R. Equal opportunity law and the construction of internal labor markets. American Journal of Sociology, 1993, 99(2), 396.

Dorado, S. Institutional entrepreneurship, partaking, and convening. Organization Studies, 2005, 26(3), 385-414.

Douglas, M. How institutions think (1st ed.). Syracuse, NY: Syracuse University Press, 1986.

Edelman, L. B. Legal ambiguity and symbolic structures: Organizational mediation of civil rights law. The American Journal of Sociology, 1992, 97(6), 1531-1576.

Eisenstadt, S. N. Cultural orientations, institutional entrepreneurs, and social change. Comparative analyses of traditional civilisations. American Journal of Sociology, 1980, 85, 840-869.

Emirbayer, M., \& Mische, A. What is agency? American Journal of Sociology, 1998, 103(4), 962-1023.

Fligstein, N. Social skill and institutional theory. American Behavioural Scientist, 1997, 40(4), 397-405.

Garud, R., Hardy, C., \& Maguire, S. Institutional entrepreneurship as embedded agency: an introduction to the special issue. Organization Studies, 2007, 28(7), forthcoming.

Garud, R., Jain, S., \& Kumaraswamy, A. Institutional entrepreneurship in the sponsorship of common technological standards: the case of Sun Microsystems and Java, Academy of Management Journal, Vol. 45: 196: Academy of Management, 2002.

Giroux, H. 'It was such a handy term': Management fashions and pragmatic ambiguity. Journal of Management Studies, 2006, 43(6), 1227-1260.

Greenwood, R., \& Suddaby, R. Institutional entrepreneurship in mature fields: the big five accounting firms Academy of Management Journal, 2006, 49(1), 27. 
Greenwood, R., Suddaby, R., \& Hinings, C. R. Theorizing change: The role of professional associations in the transformation of institutionalized fields. Academy of Management Journal, 2002, 45(1), 58-80.

Guillén, M. F. Models of management: work, authority, and organization in a comparative perspective. Chicago: University of Chicago Press, 1994.

Guler, I., Guillen, M. F., \& Macpherson, J. M. Global competition, institutions, and the diffusion of organizational practices: the international spread of ISO 9000 quality certificates. Administrative Science Quarterly, 2002, 47(2), 207-232.

Hallström, K. T. Organizing international standardization: ISO and the IASC in quest of authority. Cheltenham: Edward Elgar, 2004.

Hammer, M., \& Champy, J. Reengineering the corporation: a manifesto for business revolution. New York: Harper, 1993.

Hargadon, A. B., \& Douglas, Y. When innovations meet institutions: Edison and the design of the electric light. Administrative Science Quarterly, 2001, 46(3), 476-501.

Hirsch, P. M. From ambushes to golden parachutes: corporate takeovers as an instance of cultural framing and institutional integration. American Journal of Sociology, 1986, 91(4), 800-837.

Hirsch, P. M. Sociology without social structure: neoinstitutional theory meets brave new world. The American Journal of Sociology, 1997, 102(6), 1702-1723.

Hoffman, A. J. Institutional evolution and change: Environmentalism and the U.S. chemical industry. Academy of Management Journal, 1999, 42(4), 351-371.

Hoffman, A. J., \& Ventresca, M. J. The institutional framing of policy debates: economics versus the environment. American Behavioral Scientist, 1999, 42(8), 1368-1392.

Ibarra, H. Provisional selves: experimenting with image and identity in professional adaptation. Administrative Science Quarterly, 1999, 44(4), 764-791.

Jackson, B. Management gurus and management fashions: a dramatistic inquiry. London: Routledge, 2001.

Knights, D., \& McCabe, D. Are there no limits to authority? TQM and organizational power. Organization Studies, 1999, 20(2), 197-224.

Lawrence, T. B. Institutional strategy. Journal of Management, 1999, 25(2), 161-187.

Lawrence, T. B., \& Suddaby, R. Institutions and institutional work. In S. R. Clegg, C. Hardy, T. B. Lawrence, \& W. Nord (Eds.), The SAGE Handbook of Organization Studies: 215-254. Thousand Oaks: Sage, 2006.

Leblebici, H., Salancik, G. R., Copay, A., \& King, T. Institutional change and the transformation of interorganizational fields: An organizational history of the US radio broadcasting industry. Administrative Science Quarterly, 1991, 36(3), 333-363.

Lehr, W. Standardization: understanding the process. Journal of the American Society for Information Science, 1992, 43(8), 550-555.

Lounsbury, M., \& Crumley, E. T. New practice creation: an institutional perspective on innovation. Organization Studies, 2007, 28(7), 993-1012.

Maguire, S., Hardy, C., \& Lawrence, T. B. Institutional entrepreneurship in emerging fields: HIV/AIDS treatment advocacy in Canada. Academy of Management Journal, 2004, 47(5), 657-679.

Meidinger, E. Look who's making the rules: international environmental standard setting by non-governmental organizations. Human Ecology Review, 1997, 4(1), 52-54. 
Mendel, P. The making and expansion of international management standards: the global diffusion of ISO 9000 quality management standards. In G. S. Drori, J. W. Meyer, \& H. Hwang (Eds.), Globalization and organization: world society and organizational change: 137-166. Oxford: Oxford University Press, 2006.

Meyer, J. W., \& Rowan, B. Institutionalized organizations: formal structure as myth and ceremony. American Journal of Sociology, 1977, 83(2), 340-363.

Micklethwait, J., \& Wooldridge, A. The witch doctors: what the management gurus are saying, why it matters and how to make sense of it. London: Heinemann, 1996.

Mintrom, M., \& Vergari, S. Advocacy coalitions, policy entrepreneurs, and policy change. Policy Studies Journal, 1996, 24(3), 420-434.

Mueller, F., Proctor, S., \& Buchanan, D. Teamworking in its context(s): antecedents, nature and dimensions. Human Relations, 2000, 53(11), 1387-1424.

Orsato, R. J., den Hond, F., \& Clegg, S. R. The political ecology of automobile recycling in Europe. Organization Studies, 2002, 23(4), 639-665.

Özen, Ş., \& Berkman, Ü. Cross-national reconstruction of managerial practices: TQM in Turkey. Organization Studies, 2007, 28(6), 825-851.

Pelkmans, J. The GSM standard: explaining a success story. Journal of European Public Policy, 2001, 8(3), 432-453.

Perkmann, M., \& Spicer, A. "Healing the scars of history": projects, skills and field strategies in institutional entrepreneurship. Organization Studies, 2007, 28(1101-1122).

Perry, J., \& Noelke, A. International accounting standard setting: a network approach. Business and Politics, 2005, 7(3), 1136-1136.

Peters, T. J., \& Waterman, R. H. In search of excellence: lessons from America's best-run companies (1st ed.). New York ; London: Harper and Row, 1982.

Ruef, M., \& Scott, W. R. A multidimensional model of organizational legitimacy: hospital survival in changing institutional environments. Administrative Science Quarterly, 1998, 43(4), 877-879.

Sahlin-Andersson, K., \& Engwall, L. Carriers, flows, and sources of management knowledge. In K. Sahlin-Andersson, \& L. Engwall (Eds.), The expansion of management knowledge: carriers, flows, and sources: 3-44. Stanford, Calif.: Stanford Business Books, 2002.

Scarbrough, $\mathrm{H}$. The role of intermediary groups in shaping management fashion: the case of knowledge management. International Studies of Management and Organization, 2002, 32(4), 87-103.

Scott, W. R. Institutions and organizations. Thousand Oaks: Sage, 1995.

Shenhav, Y. From chaos to systems: the engineering foundations of organization theory, 1879-1932. Administrative Science Quarterly, 1995, 40(4).

Strang, D., \& Soule, S. A. Diffusion in Organizations and Social Movements: From Hybrid Corn to Poison Pills. Annual Review of Sociology, 1998, 24(1), 265-290.

Strang, D. B., \& Meyer, J. W. B. Institutional conditions for diffusion. Theory and Society, 1993, 22(4), 487-511.

Suddaby, R., \& Greenwood, R. Colonizing knowledge: Commodification as a dynamic of jurisdictional expansion in professional service firms. Human Relations, 2001, 54(7), 933-953. 
Thomas, J. D., \& William, Q. J., Jr. Total quality management implementation and competitive advantage: The role of structural control and exploration. Academy of Management Journal, 2001, 44(1), 158.

Tolbert, P. S., \& Zucker, L. G. The institutionalization of institutional theory. In S. Clegg, C. Hardy, \& W. Nord (Eds.), Handbook of Organization Studies: 175-190. Thousand Oaks: Sage, 1996.

Tushman, M. L., \& Anderson, P. Technological discontinuities and organizational environments. Administrative Science Quarterly, 1986, 31(3), 439-465.

Van de Ven, A. H., \& Garud, R. Innovation and industry development: The case of cochlear implants. Research on Technological Innovation, Management and Policy, 1993, 5, 146.

Viadiu, F. M., Fa, M. C., \& Saizarbitoria, I. H. ISO 9000 and ISO 14000 standards: an international diffusion model. International Journal of Operations \& Production Management, 2006, 26(2), 141-165.

Woywode, M. Global management concepts and local adaptations: working groups in the French and German car manufacturing industry. Organization Studies, 2002, 23(4), 497.

Zbaracki, M. J. The rhetoric and reality of total quality management. Administrative Science Quarterly, 1998, 43(3), 602-636.

Zeitz, G., Mittal, V., \& McAulay, B. Distinguishing adoption and entrenchment of management practices: a framework for analysis. Organization Studies, 1999, 20(5), 741-776.

Zilber, T. B. Institutionalization as an interplay between actions, meanings, and actors: the case of a rape crisis center in Israel. Academy of Management Journal, 2002, 45(1), 234-254. 


\section{Table 1: Existing research addressing the institutionalization of management fashions}

\begin{tabular}{|c|c|c|c|c|}
\hline Source & Fashionable Practice & Type of work & Activity & Actors \\
\hline \multirow[t]{3}{*}{ Baron et al. (1986) } & \multirow{3}{*}{$\begin{array}{l}\text { Human resource } \\
\text { management (work roles, } \\
\text { turnover management) }\end{array}$} & Political & $\begin{array}{l}\text { Advocacy, negotiation between unions and } \\
\text { management (eg. on seniority stipulations); vesting }\end{array}$ & Trade unions \\
\hline & & Technical & $\begin{array}{l}\text { Post-war stabilization plans, federal publications, } \\
\text { legal rulings; technical response to government } \\
\text { strategies and organizational challenges }\end{array}$ & The State, personnel professionals \\
\hline & & Cultural & Association building, identity building & Personnel professionals \\
\hline Benders et al. (1998) & $\begin{array}{l}\text { Business process } \\
\text { reengineering }\end{array}$ & Technical & Building a 'less ambitious' version of the practice & Consultants \\
\hline \multirow[t]{2}{*}{$\begin{array}{l}\text { Botzem and Quack } \\
(2006)\end{array}$} & \multirow[t]{2}{*}{ Financial reporting } & Political & $\begin{array}{l}\text { Building an central organization, enrolling } \\
\text { influential players, lobbying, conflict and struggle } \\
\text { between central players }\end{array}$ & $\begin{array}{l}\text { Professional bodies, governmental } \\
\text { bodies, international NGOs }\end{array}$ \\
\hline & & Technical & $\begin{array}{l}\text { Harmonization of standards through directives, } \\
\text { rules and standards }\end{array}$ & Professional bodies \\
\hline \multirow[t]{2}{*}{ Cole (1985) } & \multirow[t]{2}{*}{ Small group activities } & Political & $\begin{array}{l}\text { Advocacy (endorsement by trade union), } \\
\text { negotiation }\end{array}$ & $\begin{array}{l}\text { Trade unions, employer } \\
\text { organizations }\end{array}$ \\
\hline & & Technical & Elaboration of practice, publicization & $\begin{array}{l}\text { Trade organizations, professional } \\
\text { associations }\end{array}$ \\
\hline $\begin{array}{l}\text { David and Strang } \\
(2006)\end{array}$ & Total quality management & Technical & Refinement and specification of practice & Consultants \\
\hline De Cock et al. (2005) & New economy & Cultural & $\begin{array}{l}\text { Linking existing activities with new economy } \\
\text { discourse, constructing a collective identity }\end{array}$ & Companies, advertising agencies \\
\hline \multirow[t]{2}{*}{ Djelic (1998) } & \multirow[t]{2}{*}{ US production systems } & Political & $\begin{array}{l}\text { Diplomacy and advocacy of US model, building } \\
\text { linkages between actors, drafting legislation, } \\
\text { organizational creation }\end{array}$ & $\begin{array}{l}\text { National government } \\
\text { representatives, government } \\
\text { departments }\end{array}$ \\
\hline & & Technical & $\begin{array}{l}\text { Research, education, staff exchanges, development } \\
\text { of detailed plans, creation of model sites }\end{array}$ & $\begin{array}{l}\text { Specialist training colleges } \\
\text { Government departments, military }\end{array}$ \\
\hline
\end{tabular}




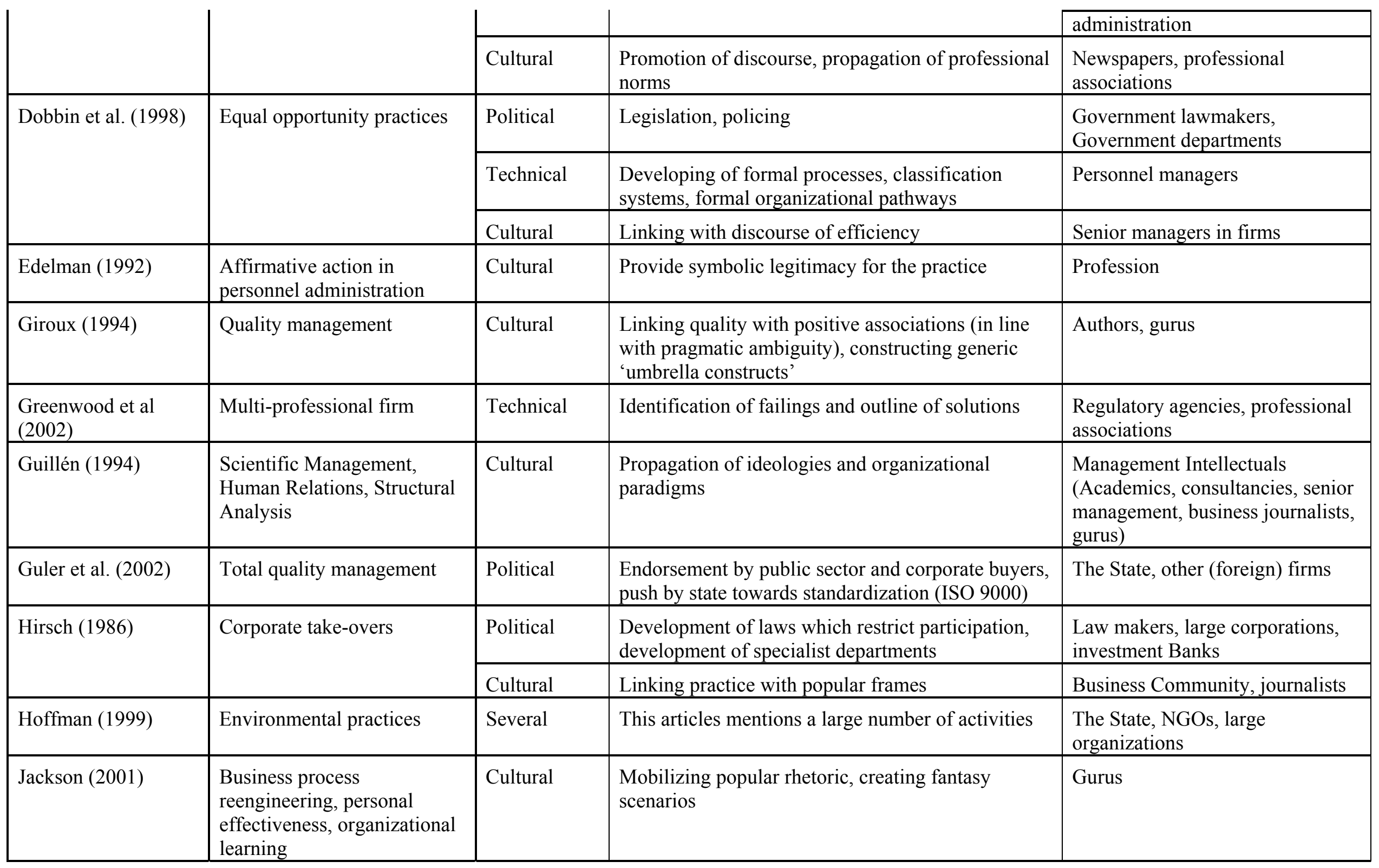




\begin{tabular}{|c|c|c|c|c|}
\hline \multirow{4}{*}{$\begin{array}{l}\text { Knights and McCabe } \\
\text { (1999) }\end{array}$} & \multirow{4}{*}{ Total quality management } & & \multirow[b]{2}{*}{ Use of hierarchical authority } & \multirow{2}{*}{ Senior Management } \\
\hline & & Political & & \\
\hline & & Technical & Creation of measurement systems & Senior Management \\
\hline & & Cultural & $\begin{array}{l}\text { Framing quality in terms of efficiency and customer } \\
\text { service }\end{array}$ & $\begin{array}{l}\text { Senior management and branch } \\
\text { management }\end{array}$ \\
\hline $\begin{array}{l}\text { Leblebici et al. } \\
\text { (1991) }\end{array}$ & $\begin{array}{l}\text { Broadcasting funded by } \\
\text { advertising }\end{array}$ & $\begin{array}{l}\text { Technical } \\
\text { work }\end{array}$ & $\begin{array}{l}\text { Theorizing (address the problem as to how to fund } \\
\text { radio broadcasting, developing a solution around } \\
\text { commercial advertising) }\end{array}$ & Advertisers, media \\
\hline \multirow[t]{2}{*}{$\begin{array}{l}\text { Lounsbury and } \\
\text { Crumley (2007) }\end{array}$} & \multirow[t]{2}{*}{ Active money management } & Technical & $\begin{array}{l}\text { Theorizing (new product categories), creation of } \\
\text { standardized education curriculum (new money } \\
\text { management practices) }\end{array}$ & Media, professional associations \\
\hline & & Political & Field-level negotiation & Industry, trade associations, \\
\hline Orsato et al. (2002) & End-of-life product recycling & Political & $\begin{array}{l}\text { Field-level negotiation to prevent legislation, } \\
\text { advocacy pushing a certain version of the practice }\end{array}$ & $\begin{array}{l}\text { State, industry associations, } \\
\text { industry participants }\end{array}$ \\
\hline $\begin{array}{l}\text { Özen and Berkman } \\
(2007)\end{array}$ & Total quality management & Cultural & $\begin{array}{l}\text { Present practice as a blueprint embracing solutions } \\
\text { to the problems at societal, organizational, and } \\
\text { individual levels }\end{array}$ & $\begin{array}{l}\text { Elite group of corporate } \\
\text { executives }\end{array}$ \\
\hline $\begin{array}{l}\text { Perry and Noelke, } \\
(2005)\end{array}$ & Fair Value Accounting & Technical & Provision of expertise for drafting legislation & $\begin{array}{l}\text { Accountancy firms, national } \\
\text { standards organizations, banks, } \\
\text { corporations, academics }\end{array}$ \\
\hline \multirow[t]{2}{*}{ Scarbrough, (2002) } & \multirow[t]{2}{*}{ Knowledge management } & Technical & $\begin{array}{l}\text { Theorization (via colonization, leading to the } \\
\text { application of practices to new areas) }\end{array}$ & Professional groups \\
\hline & & Cultural & Translation, leading to 'interpretive viability' & Consultants \\
\hline Shenhav (1995) & $\begin{array}{l}\text { Engineering approach to } \\
\text { management }\end{array}$ & Cultural & $\begin{array}{l}\text { Framing management practices in particular } \\
\text { ideologies, translating specific solutions to more } \\
\text { general solutions }\end{array}$ & $\begin{array}{l}\text { Engineers, engineering } \\
\text { associations, specialist journalists, }\end{array}$ \\
\hline Woywode (2002) & Working groups & Technical & $\begin{array}{l}\text { Plant visits, exchange of technical knowledge, } \\
\text { experimentation with model, local adaptation }\end{array}$ & Managers, consultants \\
\hline Zbaracki, (1998) & Total quality Management & Cultural & Infuse practice with claims of rational efficiency & Managers, consulting and experts \\
\hline
\end{tabular}




\section{Table 2: Institutional work, activities, and actors}

Synthesis of institutional work involved in the institutionalization of management fashions. Categories and sub-categories of institutional work inspired by Lawrence and Suddaby (2006).

\begin{tabular}{|c|c|c|c|}
\hline Work & Activity & Actors & Examples \\
\hline \multirow[t]{3}{*}{ Political } & Advocacy & $\begin{array}{l}\text { Dominant industry players } \\
\text { Unions } \\
\text { Employers organization } \\
\text { Consumer groups } \\
\text { NGOs } \\
\text { Vendors }\end{array}$ & $\begin{array}{l}\text { Small-group production (Cole, 1985) } \\
\text { Accounting standards (Botzem \& Quack, 2006; Perry } \\
\& \text { Noelke, 2005) }\end{array}$ \\
\hline & Vesting & Government & HR practices (Baron, Dobbin, \& Jennings, 1986) \\
\hline & Defining & $\begin{array}{l}\text { Standards organizations } \\
\text { Think tanks }\end{array}$ & $\begin{array}{l}\text { Total quality management (ISO 9000) (Guler, } \\
\text { Guillen, \& Macpherson, 2002) }\end{array}$ \\
\hline \multirow[t]{4}{*}{ Technical } & Theorizing & Technical consultancies & Total Quality Management (David \& Strang, 2006) \\
\hline & Standardizing & $\begin{array}{l}\text { Standards organizations, } \\
\text { consultancies, professional } \\
\text { bodies }\end{array}$ & $\begin{array}{l}\text { Total Quality Management (Guler, Guillen, \& } \\
\text { Macpherson, 2002), Accounting (Botzem \& Quack, } \\
\text { 2006) }\end{array}$ \\
\hline & Mimicry & $\begin{array}{l}\text { Standards organizations, think } \\
\text { tanks }\end{array}$ & ISO 14000 (Viadiu, Fa, \& Saizarbitoria, 2006) \\
\hline & Educating & $\begin{array}{l}\text { Universities, training providers, } \\
\text { professional associations }\end{array}$ & $\begin{array}{l}\text { US-American management practices in Europe } \\
\text { (Djelic, 1998) }\end{array}$ \\
\hline \multirow[t]{2}{*}{ Cultural } & $\begin{array}{l}\text { Constructing } \\
\text { normative } \\
\text { networks }\end{array}$ & Professional associations & $\begin{array}{l}\text { Multi-professional firm (Greenwood, Suddaby, \& } \\
\text { Hinings, 2002) }\end{array}$ \\
\hline & $\begin{array}{l}\text { Changing } \\
\text { normative } \\
\text { associations }\end{array}$ & Professional associations, gurus & $\begin{array}{l}\text { Knowledge management (Scarbrough, 2002) } \\
\text { Spread of engineering paradigm in management } \\
\text { (Shenhav, 1995) }\end{array}$ \\
\hline
\end{tabular}




\begin{tabular}{|l|l|l|l|}
\hline & & $\begin{array}{l}\text { Big five professional service firms (Suddaby \& } \\
\text { Greenwood, 2001) }\end{array}$ \\
\cline { 2 - 4 } & $\begin{array}{l}\text { Constructing } \\
\text { identity }\end{array}$ & Gurus, professional associations & $\begin{array}{l}\text { HR practices (Baron, Dobbin, \& Jennings, 1986) } \\
\text { Various (Clark \& Salaman, 1998) }\end{array}$ \\
\hline
\end{tabular}


